\title{
Risk Assessment of Lead and Cadmium in Drinking Water for School use in Nakhon Si Thammarat Province, Thailand
}

\author{
Somsiri Decharat ${ }^{1 *}\left(\mathbb{D}\right.$, Prasert Pan-in $^{2}$ \\ 'Department of Occupational health and Safety, Faculty of Health and Sports Science, Thaksin University, 222 Papayom District, Phattalung Province \\ Thailand; ${ }^{2}$ Ban Suan-eai school, Office of the Basic Education Commission area 2, Nakhon Si Thammarat, Thailand
}

This research aimed to evaluate children's health risk based on the concentration of lead $(\mathrm{Pb})$ and cadmium $(\mathrm{Cd})$ in the drinking water used by 44 primary schools. Samples were collected from bottled water, tap water, filtered tap water and raw water, for a total of 146 samples, between 1 September 2018 and 31 January 2019. The concentrations of $\mathrm{Pb}$ and $\mathrm{Cd}$ in drinking water samples were determined by graphite furnace atomic absorption spectrometry. The results showed that the concentration of $\mathrm{Pb}$ and $\mathrm{Cd}$ in bottled water samples were in the range of non-detected (ND)- $0.0180 \mathrm{mg} / \mathrm{L}$ and ND-0.0013 mg/L, respectively. The concentration of $\mathrm{Pb}$ and $\mathrm{Cd}$ in tap water samples ranged from ND-0.0250 mg/L and ND-0.0042 mg/L, respectively, from ND-0.005 mg/L and ND$0.0021 \mathrm{mg} / \mathrm{L}$, respectively, in filtered tap water samples and from ND-0.0400 mg/L and ND-0.0049 mg/L, respectively, in raw water samples. The summation of the total hazardous index (HI)-values of bottled water samples, tap water samples, filtered tap water, and raw water samples were less than 1 , was considered health-protective. The results will provide the direct evidence needed by school managers to warn learners about the health risk of ingestion exposure among children.

Keywords: Risk assessment, Lead, Cadmium, Drinking water, School

The promotion of school hygiene is typically covered along with topics like food borne disease, water borne disease, hand washing with soap, waste management and clean drinking water. WHO/UNICEF [1] presented data that $31 \%, 29 \%$, and $79 \%$ of schools lack basic water facilities, basic sanitation facilities and basic hand washing facilities, respectively. There are various categories of drinking water, including improved sources, such as piped water and boreholes, and unimproved sources, which include surface waters and unprotected drinking wells [1]. Quality of drinking water in primary schools is well recognised in its importance because adequate water intake not only presents a quality of health in children, but it may also have a positive impact on cognition of children [2-4]. The heavy metals in drinking water most often linked to human poisoning are lead $(\mathrm{Pb})$, cadmium $(\mathrm{Cd})$ and arsenic (As),

Received: June 23, 2019 Accepted: January 6, 2020

Corresponding author: Somsiri Decharat

Department of Occupational Health and Safety, Faculty of Health and Sports

Science, Thaksin University, 222 Moo 2 Papayom District, Phattalung Province 93210, Thailand.

E-mail: somsiri_9@hotmail.com

This article is available from: $h t t p s: / / e a h t . o r g /$ which can be toxic even in low doses [5]. These studies indicate the potential for significant exposure to heavy metals to occur as a result of heavy metal contamination of school drinking water sources.

Shotyk and Krachler [6] reported that water bottled in glass containers was contaminated with $\mathrm{Pb}$ due to leaching from the containers. Heavy metal concentrations are low when the water leaves the water supply, but the heavy metal concentrations may increase during transportation and storage in the distribution center [7]. Fertmann et al. [8] reported a concentration of $\mathrm{Pb}$ in tap water higher than the detection limit and showed significantly higher blood Pb levels. Badr et al. [9] found concentrations of chromium $(\mathrm{Cr}), \mathrm{Pb}$ and iron $(\mathrm{Fe})$ in drinking water that there were significantly higher in tap water samples compared to bottled water. In addition, blood creatinine and urea levels were positively correlated with $\mathrm{Cr}$ and $\mathrm{Cd}$ levels in subjects who were mainly drinking tap water. Filtration is a common way to obtain pure drinking water by removing particles and microorganisms based on size exclusion. Conventional water treatment systems were found, in general, while advanced technologies such as Actiflo clarification sys- 
tem, ultra-membrane filtration, dissolved air flotation (DAF) and ozone were only used at a few water treatment plants [10]. Ultra-membrane filtration uses transmembrane pressure to remove $\mathrm{Cr}$, $\mathrm{Cd}$, zinc $(\mathrm{Zn})$, copper $(\mathrm{Cu})$, nickel $(\mathrm{Ni})$, and $\mathrm{Pb}$, with removal percentages ranging from $92 \%$ to $100 \%$ [11]. The neurotoxic effects of $\mathrm{Pb}$ in children, even at low doses, are well understood $[12,13]$. Cd is extremely toxic, even at low concentrations, bioaccumulates in organisms and ecosystems, and has a long biological half-life in the human body, ranging from 10 to 33 years. Long-term exposure to Cd also induces renal damage. The contamination of water is directly related to water pollution, and the quality of ground and surface water sources needs to be assessed [14].

The main sources of drinking water in the primary schools are bottled water, tap water and filtered water. The water supply from surface water is used as drinking water in a few schools and raw water is also used to clean the containers, clean vegetables, etc. The concentrations of both $\mathrm{Pb}$ and $\mathrm{Cd}$ and the health risk from exposure need to be considered. The aims of this study were to investigate the concentration of $\mathrm{Pb}$ and $\mathrm{Cd}$ in drinking water samples and to assess the health risk from exposure of $\mathrm{Pb}$ and $\mathrm{Cd}$ in drinking water, which is used to service schools.

\section{Materials and Methods}

This cross-sectional study was conducted between 1 September 2018 and 31 January 2019 in public primary schools located in four districts, including the Phipun, Chawang, Chang Khang and Tham Phannara districts in the Nakhon Si Thammarat province, Thailand, which is supported by Nakhon Si Thammarat primary education service area 2. 44 public primary schools were selected using a purposive sampling method. A total of 146 drinking water samples were collected, including 48 bottled water samples, 44 tap water samples, 30 filtered tap water samples and 24 raw water samples.

\section{Samples collection, Samples preparation, Measuring, and Analysis}

Drinking water samples were collected from sources of drinking water and in the primary schools including 48 bottled water, 44 tap water, 30 filtered water and 24 raw water. The drinking water samples were collected in prewashed. Most of the drinking water samples were obtained directly from tap after allowing the water to run for at least 5 minutes. Water samples were stored in 50 polyethylene bottles previously washed in nitric acid. The water samples were acidified with $50 \%(\mathrm{v} / \mathrm{v})$ nitric acid (E. Merck, Darmstadt, Germany) to brink the $\mathrm{pH}$ to less than 2 and analyzed within two days. All samples were filtered prior to analysis using Whatman ${ }^{\circ}$ Ashless Filters, Grade 541, (Whatman, London, UK) to reduce the suspended solids associated with the risk of obstructing the capillary tubing in the instrument.

$\mathrm{Pb}$ and $\mathrm{Cd}$ concentrations were determined by graphite furnace atomic absorption spectrometry (GFAAS, PerkinElmer, Analyst 800). The standards and dilution standards for analyses were prepared by using $1.0 \mathrm{~mol} / \mathrm{L}$ of nitric acid to dilute stock solutions of $\mathrm{Pb}$ and $\mathrm{Cd}(1000 \mathrm{mg} / \mathrm{L})$. The calibration solutions and $20 \mu \mathrm{L}$ of samples were pipetted into the graphite tube for measurement. The standard reference material (Trace element dissolved in water) was used for evaluating methods used to measure $\mathrm{Pb}$ and $\mathrm{Cd}$ in the drinking water samples. All samples were analyzed in triplicate. Detection limits of GFAAS were $0.0020 \mathrm{mg} / \mathrm{L}$ for $\mathrm{Pb}$ and $0.0001 \mathrm{mg} / \mathrm{L}$ for $\mathrm{Cd}$.

\section{Risk assessment}

The test method of the US Environmental Protection Agency (U.S. EPA 1989) [14] was used to calculate chronic daily intakes (CDI) from incidental ingestion of $\mathrm{Pb}$ and $\mathrm{Cd}$ in drinking water as follows:

$$
\mathrm{CDI}(\mathrm{mgkg}-\mathrm{d})=\frac{\mathrm{C} \times \mathrm{IR} \times \mathrm{EF} \times \mathrm{ED}}{\mathrm{BW} \times \mathrm{AT}}
$$

where $\mathrm{C}$ is the concentration of $\mathrm{Pb}$ and $\mathrm{Cd}$ in drinking water $(\mathrm{mg} / \mathrm{L})$ (data from laboratory analysis), IR is the ingestion rate (2 L/day for age over 6 years old, U.S. EPA 1989) [15], EF is the exposure frequency (360 days/year) [16], ED is the exposure duration (6 years) [16], BW is the body weight (average of body weight of students $35 \mathrm{~kg}$, from questionnaires), AT is the average time of exposure $(\mathrm{ED} \times 365$ days/year) [17]. When hazardous quotients (HQ) and hazard index (HI) values are less than one, there is no risk to the population, but if these values exceed one, there may be concern for potential non-carcinogenic effects [15].

\section{Data analysis}

Statistical analyses were performed using the statistical package SPSS 15.0. Descriptive statistics were applied to determine concentrations of $\mathrm{Pb}$ and $\mathrm{Cd}$ in the drinking water from the public primary schools.

\section{Results}

The samples of drinking water were collected for analysis from 44 primary schools. The following water quality parameters were measured: temperature, $\mathrm{pH}$ and turbidity. The temperature, $\mathrm{pH}$ and turbidity ranges of bottled water samples (48 
Table 1. The physical and chemical properties of drinking water use in the primary schools

\begin{tabular}{|c|c|c|c|c|c|c|c|}
\hline \multirow[b]{2}{*}{ Sources } & \multirow{2}{*}{$\begin{array}{l}\text { Temperature } \\
\text { Range }\left({ }^{(} \mathrm{C}\right)\end{array}$} & \multirow{2}{*}{$\begin{array}{c}\mathrm{pH} \\
\text { Range }\end{array}$} & \multirow{2}{*}{$\begin{array}{c}\text { Turbidity } \\
\text { Range (NTU) }\end{array}$} & \multicolumn{2}{|c|}{ Lead $(\mathrm{Pb})$ concentrations ${ }^{\mathrm{a}}(\mathrm{mg} / \mathrm{L})$} & \multicolumn{2}{|c|}{ Cadmium (Cd) concentrations ${ }^{\mathrm{a}}(\mathrm{mg} / \mathrm{L})$} \\
\hline & & & & $\begin{array}{c}\mathrm{n} \leq 0.01 \mathrm{mg} / \mathrm{L}(\%) \\
\text { (range } \mathrm{mg} / \mathrm{L} \text { ) }\end{array}$ & $\begin{array}{c}\mathrm{n}>0.01 \mathrm{mg} / \mathrm{L}(\%) \\
\text { (range } \mathrm{mg} / \mathrm{L} \text { ) }\end{array}$ & $\begin{array}{c}\mathrm{n} \leq 0.003 \mathrm{mg} / \mathrm{L}(\%) \\
\text { (range } \mathrm{mg} / \mathrm{L} \text { ) }\end{array}$ & $\begin{array}{c}\mathrm{n}>0.003 \mathrm{mg} / \mathrm{L}(\%) \\
\text { (range } \mathrm{mg} / \mathrm{L})\end{array}$ \\
\hline Bottled water $(n=48)$ & $26.0-27.1$ & $7.0-7.3$ & ND & $\begin{array}{c}44(91.66) \\
(\mathrm{ND}-0.0040)\end{array}$ & $\begin{array}{c}4(8.34) \\
(0.012-0.0180)\end{array}$ & $\begin{array}{c}48(100.00) \\
(N D-0.0013)\end{array}$ & 0 \\
\hline Tap water $(n=44)$ & $26.1-26.5$ & $6.8-7.1$ & $1.0-1.3$ & $\begin{array}{c}36(81.81) \\
(\text { ND- } 0.0030)\end{array}$ & $\begin{array}{c}8(18.19) \\
(0.0200-0.0250)\end{array}$ & $\begin{array}{c}40 \text { (90.91) } \\
\text { (ND-0.0015) }\end{array}$ & $\begin{array}{c}4(9.09) \\
(0.0031-0.0042)\end{array}$ \\
\hline Filtered tap water $(n=30)$ & $27.0-27.3$ & $6.9-7.2$ & ND & $\begin{array}{l}30(100.00) \\
(N D-0.005)\end{array}$ & 0 & $\begin{array}{l}30(100.00) \\
(N D-0.0021)\end{array}$ & 0 \\
\hline Raw water $(n=24)$ & $26.0-27.1$ & $6.9-7.8$ & $3-3.4$ & $\begin{array}{c}16(66.66) \\
\text { (ND-0.0049) }\end{array}$ & $\begin{array}{c}8(33.34) \\
(0.0180-0.0400)\end{array}$ & $\begin{array}{c}20(83.33) \\
(N D-0.0024)\end{array}$ & $\begin{array}{c}4(16.67) \\
(0.0031-0.0049)\end{array}$ \\
\hline
\end{tabular}

aWHO guide limit level.

$\mathrm{ND}=$ not detectable. $\mathrm{LOD}=$ limit of detection.

LOD for Lead $=0.0025 \mathrm{mg} / \mathrm{L}$. LOD for cadmium $=0.00016 \mathrm{mg} / \mathrm{L}$.

Table 2. Chronic daily intake (CDI), Hazard Quotient $(\mathrm{HQ})$ and Hazard Index $(\mathrm{HI})$ in children due to lead $(\mathrm{Pb})$ and cadmium $(\mathrm{Cd})$ from different drinking water sources.

\begin{tabular}{|c|c|c|c|c|c|}
\hline Sources & $\begin{array}{c}\mathrm{CDI} \text { of } \mathrm{Pb} \text { (range, average } \pm \\
\mathrm{SD} \text { ) }\end{array}$ & $\begin{array}{c}\mathrm{CDI} \text { of } \mathrm{Cd} \\
\text { (range, average } \pm \mathrm{SD} \text { ) }\end{array}$ & $\begin{array}{c}\mathrm{HQ} \text { value of } \mathrm{Pb} \\
\text { (range, average } \pm \mathrm{SD} \text { ) }\end{array}$ & $\begin{array}{c}\mathrm{HQ} \text { value of } \mathrm{Cd} \\
\text { (range, average } \pm \mathrm{SD} \text { ) }\end{array}$ & $\mathrm{HI}$ \\
\hline Bottled water $(n=24)$ & $\begin{array}{c}\mathrm{ND}-2.37 \times 10^{-3} \\
\left(2.76 \times 10^{-4} \pm 5.67 \times 10^{-4}\right)\end{array}$ & 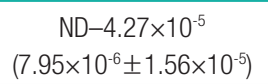 & $\begin{array}{c}0-0.2367 \\
(0.02756 \pm 0.05668)\end{array}$ & $\begin{array}{c}0-0.0142 \\
(0.0026 \pm 0.0052)\end{array}$ & 0.2510 \\
\hline Tap water(n = 22) & $\begin{array}{c}N D-3.29 \times 10^{-3} \\
\left(5.66 \times 10^{-4} \pm 1.15 \times 10^{-4}\right)\end{array}$ & $\begin{array}{c}\text { ND-1.38 } \times 10^{-4} \\
\left(2.23 \times 10^{-5} \pm 3.62 \times 10^{-5}\right)\end{array}$ & $\begin{array}{c}0-0.3288 \\
(0.05661 \pm 0.11521)\end{array}$ & $\begin{array}{c}0-0.0460 \\
(0.0074 \pm 0.0120)\end{array}$ & 0.3748 \\
\hline Filtered tap water $(n=15)$ & $\begin{array}{c}N D-6.58 \times 10^{-4} \\
\left(8.45 \times 10^{-5} \pm 1.97 \times 10^{-4}\right)\end{array}$ & $\begin{array}{c}N D-6.90 \times 10^{-5} \\
\left(7.51 \times 10^{-6} \pm 2.01 \times 10^{-5}\right)\end{array}$ & $\begin{array}{c}0-0.0657 \\
(0.00845 \pm 0.01971)\end{array}$ & $\begin{array}{c}0-0.0230 \\
(0.0025 \pm 0.0067)\end{array}$ & 0.0888 \\
\hline Raw water $(n=12)$ & $\begin{array}{c}N D-5.52 \times 10^{-3} \\
\left(1.58 \times 10^{-3} \pm 2.13 \times 10^{-3}\right)\end{array}$ & $\begin{array}{c}N D-1.61 \times 10^{-4} \\
\left(5.67 \times 10^{-5} \pm 5.15 \times 10^{-5}\right)\end{array}$ & $\begin{array}{c}0-0.5523 \\
(0.15879 \pm 0.21339)\end{array}$ & $\begin{array}{c}0-0.0536 \\
(0.0189 \pm 0.0172)\end{array}$ & 0.6060 \\
\hline
\end{tabular}

$\mathrm{ND}=$ not detectable.

$\mathrm{SD}=$ Standard deviation

samples) were $26.0-27.1^{\circ} \mathrm{C}, \mathrm{pH} 7.0-7.3$ and not detected (ND), respectively. For tap water samples (44 samples), the temperature, $\mathrm{pH}$ and turbidity ranges were $26.1-26.5^{\circ} \mathrm{C}, \mathrm{pH}$ 6.8-7.1 and 1.0-1.3 NTU, respectively. The ranges for the filtered tap water samples ( 30 samples) were $27.0-27.3^{\circ} \mathrm{C}, \mathrm{pH}$ 6.9-7.2 and not detected and the ranges for the raw water samples $(24$ samples) were $26.0-27.1^{\circ} \mathrm{C}$, $\mathrm{pH}$ 6.9-7.8, and 3.0-3.4 NTU, respectively, for temperature, $\mathrm{pH}$ and turbidity.

The concentration of $\mathrm{Pb}$ and $\mathrm{Cd}$ ranged from ND-0.0180 $\mathrm{mg} / \mathrm{L}$ and ND-0.0013 $\mathrm{mg} / \mathrm{L}$ in bottled water samples, respectively, from ND-0.0250 mg/L and ND- $0.0042 \mathrm{mg} / \mathrm{L}$ in tap water samples, respectively, from ND-0.005 mg/L and ND$0.0021 \mathrm{mg} / \mathrm{L}$ in filtered tap water samples, respectively, and from ND-0.0400 mg/L and ND-0.0049 mg/L in raw water samples, respectively (Table 1).

An estimation of CDI from the drinking water through ingestion showed that $\mathrm{Cd}$ intake was lower than $\mathrm{Pb}$ intake in all samples (Table 2). The highest $\mathrm{Pb}$ intake was found in raw water (5.52 x10-3 mgkg-d), while the greatest Cd intake was also found in raw water (1.61 x 10-4 mgkg-d). With respect to HQ that are regularly applied to evaluate human health risk from intake of drinking water through the ingestion pathway, the greatest $\mathrm{HQ}$ of $\mathrm{Pb}$ and $\mathrm{Cd}$ was 0.5523 and 0.0536 in raw water, respectively. The summation of the total HI-values of bottled water samples, tap water samples, and raw water samples were $0.2510,0.3748,0.0888$ and 0.606 , respectively (Table 2).

\section{Discussion}

The results of temperature, $\mathrm{pH}$, and turbidity of all samples in this study did not exceed the recommended permissible limits set by Thai ministry of public health and World Health Organization (WHO) $[18,19]$. The concentration of $\mathrm{Pb}$ found in $8.34 \%$ of the bottled water samples exceeded the recommended permissible limit of $\mathrm{Pb}$ in guidelines for drinking water quality. In contrast, the Cd concentration in bottled water samples did not exceed the permissible value of $\mathrm{Cd}$ for the drinking water quality standard. Bottled water in Thailand comes from many different brands and types, primarily based on the purification process, including reverse osmosis, ultraviolet treatment, ozone treatment and mineral or spring water. However, a portion of bottled water brands in this study were produced in a factory from the local community, and the production process has yet to be standardised, as $\mathrm{Pb}$ was detected 
in some of the brands. However, the large bottled water companies in Thailand have large water purification facilities and are more likely to stick to a good standardized production process.

The concentrations of $\mathrm{Pb}$ and $\mathrm{Cd}$ in tap water samples were $18.19 \%$ and $9.09 \%$, respectively, which exceeded the permissible values in guidelines for drinking water quality. Some studies reported the dissolution of $\mathrm{Pb}$ in tap water when $\mathrm{Pb}$ free taps were used, which was attributed to in-line brass fittings within household plumbing systems, thus, suggesting the use of a tap made from a material that does not contain $\mathrm{Pb}$, such as stainless-steel taps $[20,21]$. In addition, flushing the taps before consumption for two or three minutes is a technique that can be help reduce the concentration of heavy metal contaminants [20, 22, 23]. Furthermore, some suggest that the presence of chlorine and other pollutants in tap water, such as trihalomethanes (THMs), potentially create a commonly formed carcinogen, such as chloroform [24]. In addition, fluoride can be present in tap water, particularly in the mountains, as there is naturally more fluoride in the water there than elsewhere. In Thailand, the highest fluoride content was found in samples from the central and eastern regions [25]. An excess of fluoride in the water can have detrimental effects on teeth, especially during the phase of growth. Some studies clearly established that fluoride primarily produces effects on skeletal tissues (bones and teeth) [26,27].

The concentration of $\mathrm{Pb}$ and $\mathrm{Cd}$ in filtered tap water samples did not exceed the permissible value in guidelines for drinking water quality set by Thai ministry of public health and WHO $[18,19]$. Khulbe and Matsuura [28] reported that membranes for membrane adsorption, which have the dual function of membrane filtration and adsorption, are very effective in removing trace amounts of pollutants, such as cationic heavy metals, anionic phosphates and nitrates. Al-Rashdi et al. [29], reported the removal of some heavy metals including $\mathrm{Cu}, \mathrm{Cd}$, manganese ( $\mathrm{Mn}), \mathrm{Pb}$ and As from aqueous solutions using adsorption and nanofiltration membrane technologies.

The concentration of $\mathrm{Pb}$ and $\mathrm{Cd}$ in $33.34 \%$ and $16.67 \%$ of raw water samples, respectively, exceeded the recommended permissible limit in guidelines for drinking water quality. The quality of surface water in an area is highly affected by human activities in that area [30]. In this study, agricultural activities may have a profound effect on the surface water [31,32] because the agricultural areas, para rubber, rice farming and garden fruit, were located near the surface water source. Agricultural activities can be related to the surface contamination of pesticides, heavy meals and other pollutants. Thus, raw water samples are not suitable for drinking purposes unless it is treated by the water agencies.
The summation of the total HI-values of bottled water samples, tap water samples, drinking water samples and raw water samples were less than 1; suggesting there was considered health-protective. However, minimizing potential human exposure is still adverse health effects. Based on several studies, $\mathrm{Pb}$ is best known for impeding children's growth, as it accumulates in the long bones and causes bone damage [33-36]. In addition, low Cd exposure is still limited and has had opposing results. Data reported from the National Health and Nutrition Examination Survey (NHANES) in U.S. showed a positive link between child urinary $\mathrm{Cd}$ and the prevalence of learning disabilities and special education among 6-15-year-olds, however, a non-significant lower prevalence of attention deficit hyperactivity disorder (ADHD) was related to the exposure [5].

\section{Conclusion}

$\mathrm{Pb}$ and $\mathrm{Cd}$ concentrations were determined from the drinking water of select primary schools in Nakhon Si Thammarat province, Thailand. The concentrations of $\mathrm{Pb}$ and $\mathrm{Cd}$ detected in filtered tap water did not exceed the recommended permissible limits. The results provide the direct evidence needed by school managers to warn learners about the health risk of ingestion exposure among children. Thus, should control the production of bottled water in local water production factories to ensure the factories have the appropriate technology to meet the drinking water standards. In addition, raw water is not suitable for drinking purposes unless it is treated by the water agencies. However, toxicity tests such as in vitro or in vivo toxicity test, are important components in assessing the impact of heavy metals on aquatic ecosystems because they reveal toxic effect of complex chemical mixtures [37]. Thus, toxicity tests should be carried out in the drinking water.

\section{Conflict of interest statement}

The author has no conflict of interest associated with the material presented in this paper.

\section{Acknowledgement}

This research was supported by the Faculty of Health and Sports Science, Thaksin University.

\section{References}

1. World Health Organization / United Nations International Children's Emergency Fund (WHO/UNICEF). Drinking water, sanitation and 
hygiene in schools - global baseline report 2018 [cited March 25, 2018]. Available from: https://www.unicef.org/media/47671/file/ JMP-WASH-in-Schools-ENG.pdf .

2. United State Environmental Protection Agency (US EPA). Safe drinking water act [cited March 25, 2018]. Available from: http://water.epa. gov/lawsregs/guidance/sdwa/index.cfm.

3. Popkin BM, D'Anci KE, Rosenberg IH. Water, hydration, and health. Nutr Rev 2010; 68(8):439-458.

4. Patel AI, Bogart LM, Uyeda KE, Rabin A, Schuster MA. Perceptions about availability and adequacy of drinking water in a large California school district. Prev Chronic Dis 2010;7(2):A39.

5. Ciesielski T, Weuve J, Bellinger DC, Schwartz J, Lanphear B, Wright RO. Cadmium Exposure and Neurodevelopmental Outcomes in U.S. Children. Environ Health Perspect 2012;120(5):758-763.

6. Shotyk W, Krachler M. Lead in Bottled waters: contamination from glass and comparison with pristine groundwater. Environ Sci Technol 2007;41(10):3508-3513.

7. Fontenay F, Andersen A, Werner W, Erning W. Nickel and lead release to drinking water-Danish and European results [cited 2015 March 25]. Available from: http://www.forcetechnology.com/NR/rdonlyres/ 68BF09BF-5C28-416E-9F89-E8C17208B753/2635/EUROCORR_ 2009_Nice_711September2009_web.pdf.

8. Fertmann R, Hentschel S, Dengler D, Janssen U, Lommel A. Lead exposure by drinking water: an epidemiological study in Hamburg, Germany. Int J Hyg Environ Health 2004; 207(3):235-244.

9. Badr E, Agrama A, Badr S. Heavy metals in drinking water and human health, Egypt. Nutri Food Sci 2011;41(3):210-217.

10. Puncak Niaga Holdings. Berhad. Water treatment [cited March 20, 2018]. Available from: http://www.puncakniaga.com.my/pnhb2/index.php/core-businesses/intro-on-landing-pg-water/water-treatment.

11. Fu F, Wang Q. Removal of heavy metal ions from wastewaters: a review. J Environ Manage 2011;92(3):407-418.

12. Agency for Toxic Substances and Disease Registry (ATSDR). Lead (Pb) Toxicity: what are the physiological effects of lead exposure? [cited June 12, 2017]. Available from: https://www.atsdr.cdc.gov/csem/ lead/docs/CSEM-Lead_toxicity_508.pdf

13. World Health Organization (WHO). Guidelines for drinking-water quality, 4th ed.; World Health Organization 2011.

14. Ehi-Eromosele C, Okiei W. Heavy metal assessment of ground, surface and tap water samples in Lagos metropolis using anodic stripping voltammetry. Resour Environ 2012;2(3): 82-86.

15. United State Environmental Protection Agency (US EPA). Risk assessment guidance for superfund volume I: human health evaluation manual (Part A). United State Environmental Protection Agency (US EPA).1989. EPA/540/1-89/002.

16. World Health Organization (WHO). Growth reference data for 5-19 years [cited March 20, 2018]. Available from: http://www.who.int/ growthref/en.

17. Zheng N, Liu J, Wang Q, Liang Z. Health risk assessment of heavy metal exposure to street dust in the zinc smelting district, northeast of China. Sci Total Environ 2010: 408(4):726-733.

18. Royal Government Gazette. Drinking water in Thai Source: Notification of the Ministry of Public Health, No. 61 /B.E. 2524 (1981) Regarding to drinking water in sealed container 1981;98(157)
19. World Health Organization (WHO). Chemicals of health significance as described by World Health Organization Guidelines (WHO) for Drinking-water Quality in third edition (2008) and fourth edition (2011). 2011. [cited March 21, 2018]. Available from: https://www.epd.gov.hk/ eia/register/report/eiareport/eia_2242014/EIA/app/app02.02.pdf

20. Harvey PJ, Handley HK, Taylor MP. Widespread copper and lead contamination of household drinking water, New South Wales, Australia. Environ Res 2016; 151:275-285.

21. Ng DQ, Lin YP. Evaluation of lead release in a simulated lead-free premise plumbing system using a sequential sampling approach. Int J Environ Res Public Health 2016;13(3):E266

22. Environmental health standing committee (enHealth) of the Australian health protection principal committee. Health guidance statement lead in drinking water from some plumbing products [cited March 18, 2018]. Available from: http://www.health.gov.au/internet/ main/publishing.nsf/content/A12B57E41EC9F326CA257BF0001F9E 7D/\$File/Lead-plumbing-products-Guidance-Statement-July2018. pdf.

23. Minnesota Department of Health. Important information on how to protect your health: let it run and get the lead out! [cited March 19, 2018]. Available from: http://www.health.state.mn.us/divs/eh/water/factsheet/com/letitrunenglish.pdf.

24. Canosa J, Martí V. Design of stripping columns applied to drinking water to minimize carcinogenic risk from trihalomethanes (THMs). Toxics 2018; 6(1):18.

25. Chuckpaiwong S, Nakornchai S, Surarit R, Soo-ampon S, Kasetsuwan R. Fluoride in water consumed by children in remote areas of Thailand. Southeast Asian J Trop Med Public Health 2000; 31(2):319-324.

26. United States Department of Agriculture (USDA). Fluoride database of selected beverages and foods [cited March 15, 2018]. Available from: http://www.ars.usda.gov/services/docs.htm?docid=6312.

27. Fawell J, Bailey K, Chilton J, Dahi E, Fewtrell L, Magara Y. Fluoride in drinking-water. London: World Health Organization (WHO) [cited March 15, 2018]. Available from: https://apps.who.int/iris/bitstream/ handle/10665/43514/9241563192_eng.pdf?sequence=1\&isAllowed=y.

28. Khulbe KC, Matsuura T. Removal of heavy metals and pollutants by membrane adsorption techniques. Appl Water Scie 2018;8:19.

29. Al-Rashdi B, Somerfield C, Hilal N. Heavy metals removal using adsorption and nano filtration techniques. Sep Purif Rev 2011;40:209259.

30. World Health Organization (WHO). Guidelines for drinking water quality vol. 2: health criteria and other supporting information. 2nd ed. World Health Organization. 1998.

31. Lal R, Stewart BA. Soil process and water quality. Soil processes and water quality. Boca Raton, CRC Press, 1994.

32. Kim DW, Woo HD, Joo J, Park KS, Oh SY, Kwon HJ et al. Estimated long-term dietary exposure to lead, cadmium, and mercury in young Korean children. Eur J Clin Nutr 2014; 68:1322-1326.

33. Kaji M, Nishi Y. Lead and growth. Clin Pediatr Endocrinol 2006;15(4): 123-128.

34. Yang H, Huo X, Yekeen TA, Zheng Q, Zheng M, Xu X. Effects of lead and cadmium exposure from electronic waste on child physical growth. Environ Sci Pollut Res Int 2013; 20(7): 4441-4447.

35. Min KB, Min JY, Cho SI, Kim R, Kim H, Paek D. Relationship between low blood lead levels and growth in children of white-collar civil ser- 
vants in Korea. Int J Hyg Environ Health 2008; 211(1-2):82-87.

36. Centers for Disease Control and Prevention (CDC). CDC's healthy homes and lead poisoning prevention program [cited March 15, 2018]. Available from: https://www.cdc.gov/nceh/lead/data/defini- tions.html.

37. Jaishankar M, Tseten T, Anbalagan N, Mathew BB, Beeregowda KN. Toxicity, mechanism and health effects of some heavy metals. Interdiscip Toxicol 2014;7(2):60-72 . 